\title{
Energetic characterization and evaluation of briquettes produced from naturally colored cotton waste
}

\author{
Janduir Egito da Silva ${ }^{1,2}$ (1) Dulce Maria de Araújo Melo ${ }^{3}$ - Marcus Antônio de Freitas Melo ${ }^{1}$. \\ Emerson Moreira de Aguiar ${ }^{4}$. Alexandre Santos Pimenta ${ }^{4}$. Everaldo Paulo de Medeiros ${ }^{5}$. \\ Guilherme Quintela Calixto ${ }^{1}$. Renata Martins Braga ${ }^{1,4}$
}

Received: 6 July 2018 / Accepted: 4 March 2019

(C) Springer-Verlag GmbH Germany, part of Springer Nature 2019

\begin{abstract}
Cotton crops generate millions of tons of lignocellulosic waste in Brazil that could be used in energy generation; however, the main destination of this raw material is soil incorporation. The aim of this work was to perform an energetic characterization and evaluation of briquettes produced from different agricultural waste of naturally colored cotton for power generation. The cultivars Brasil Sementes (BRS) Jade and Topazio were studied, with white cotton (BRS 286) as standard for comparison purposes. Two different parts of each species, stalk and cotton shell, were analyzed by bulk density, proximate analysis, higher heating value, cellulose, hemicellulose, protein, fat and lignin content, thermogravimetric analysis, and briquette mechanical strength. The results of the energetic characterization indicated a higher energetic potential of the colored species when compared with the white cotton, especially because of the volatile matter content, fixed carbon, and higher heating value. The briquette mechanical strength was higher in the samples formulated by a mixture of stalk and shell. Finally, it was concluded that the waste from colored cotton cultivars, Jade and Topazio, is capable to generate briquettes with good mechanical and physicochemical characteristics, especially those formed by the mixture of stalk and shell.
\end{abstract}

Keywords Cotton crop waste $\cdot$ Natural colored cotton $\cdot$ Energetic characterization $\cdot$ Biomass densification $\cdot$ Briquettes $\cdot$ Briquette mechanical strength

Responsible editor: Philippe Garrigues

Janduir Egito da Silva

janduir.egito@gmail.com

Dulce Maria de Araújo Melo

daraujomelo@gmail.com

Marcus Antônio de Freitas Melo

marcus@eq.ufrn.br

Emerson Moreira de Aguiar emersonmaufrn@gmail.com

Alexandre Santos Pimenta aspimenta@ufrnet.br

Everaldo Paulo de Medeiros

everaldo.medeiros@embrapa.br

Guilherme Quintela Calixto guilhermeqc20@gmail.com
Renata Martins Braga

renatabraga.r@gmail.com

1 PPGEQ, Universidade Federal do Rio Grande do Norte, Natal, RN, Brazil

2 Campus Universitário Lagoa Nova, Universidade Federal do Rio Grande do Norte - UFRN, Natal, RN CEP 59078-970, Brazil

3 Instituto de Química, Universidade Federal do Rio Grande do Norte, Natal, RN, Brazil

4 EAJ, Universidade Federal do Rio Grande do Norte, Macaíba, RN, Brazil

5 Empresa Brasileira de Pesquisa Agropecuária, Embrapa Algodão, Campina Grande, PB, Brazil 


\section{Introduction}

Various agro-industrial wastes have been assessed due to their energetic potential for power generation, once that they have energy value and produced in large quantities (Nikhilesh et al. 2018; Shone and Jothi 2016). However, these materials are usually discharged into the environment without an appropriate use. In particular, the cotton crop waste must be highlighted: after the lint harvest, the residue is buried into the ground to avoid pests, although this practice has a high energy demand and often degrades the soil structure (Coates 2000). This practice causes impacts on the soil due to the use of tractor, causing erosion and, over time, it can compact a layer of soil that makes the cotton cultivation unfeasible (Bianchini 2004).

Currently, Brazil is the world's fifth largest producer of cotton; in the 2015/2016 period, the country had a harvest of approximately $1.3 \mathrm{Mt}$ (CONAB 2017). In addition, it is included in this total the colored cotton species developed by EMBRAPA Algodão, which are produced in smaller amount than the conventional white cotton. Even though its production is growing and consistent, since they do not use dyes, these products have a high relevance for the textile industry, since they generate a significant reduction in the consumption of water, energy, and toxic chemicals used to manufacture a textile with good quality fibers. Therefore, naturally colored cotton fibers are ecologically correct, economical, and beneficial to human health when compared with the conventional white fibers, and due to these advantages, they have been favored and increasingly used in textile production (Zhu et al. 2006). However, the increase in the production of cotton fibers promotes the generation of agricultural waste.

The white cotton crop waste production is 2.9 times higher than the production of lint (Jenkins and Sumner 1986). The amount of crop waste produced for the colored cotton is lower than white cotton, being estimated as approximately 2 times more waste than lint.

The cotton crop waste has low density, so their direct use in energy generation becomes impracticable. However, it is important to assess the energy potential of this agricultural waste, since large volumes are produced. A way to enable the use of low-density biomasses is by applying a densification process, producing pellets or briquettes that create a homogeneous fuel with high energy density (Moreno et al. 2016). When the lignocellulosic agricultural waste is submitted to certain conditions of pressure and temperature during the briquette production, they can contribute significantly in the generation of energy (Oliveira et al. 2017). Some studies report the energy potential of white cotton waste in the combustion process ( $\mathrm{Ji}$ Lu et al. 2008; Madhu et al. 2016; Ali et al. 2015); however, no study regarding colored cotton waste was evidenced in the literature.

Therefore, this study aims the energetic characterization and evaluation of briquettes produced with raw-colored cotton and white cotton cultivars harvested in Northeast of Brazil for power generation.

\section{Materials and methods}

\section{Biomass preparation}

The biomass were collected during the second semester of 2017, in the experimental field of the Paraíba State Agricultural Research Company (EMEPA), located at Lagoa Seca $\left(07^{\circ} 10^{\prime} 15^{\prime \prime} \mathrm{S} ; 35^{\circ} 51^{\prime} 13^{\prime \prime} \mathrm{W}\right.$. Gr., elevation of $\left.634 \mathrm{~m}\right)$, Paraíba, Brazil. The studied cultivars were two natural colored BRS type (Brazil Sementes), called Jade and Topazio, and a sample of conventional white cotton, called Branco BRS 286 as standard for comparison purposes. Two different parts of each cultivar, stalk and shell (Fig. 1), and a mixture 1:1 ratio between them were analyzed. The samples were dried in an industrial oven with air circulation at $100{ }^{\circ} \mathrm{C}$, then grinding at a Willey mill, using a mesh of $5 \mathrm{~mm}$. Nine samples, containing $0.5 \mathrm{~kg}$ of biomass each, were prepared and named as follow: B_ST, B_SH, B_1:1, T_ST, T_SH, T_1:1, J_ST, J_SH, J_1:1. From left to right, the first letter is referring to their species, the second and third letter are associated to different parts (ST-stalk and SH-shell) of the cotton plant, and, last, the numbers indicate the proportions used as show on description in Table 1.

\section{Biomass characterization}

The dry-based biomass samples have their moisture content fixed to $8 \%$ by controlled addition of moisture using a spray containing distilled water and storing during $24 \mathrm{~h}$ in a sealed plastic bag for better moisture homogenization. The samples were characterized according to ASTM E1755-01 (2015) and E872-82 (2013) for determination of ash and volatile matter, respectively; considering a moisture content of $8 \%$, the fixed carbon was calculated by the difference, fixed carbon $=100$ $8 \%$ - ash $\%$ - volatile $\%$. The bulk density was determined according to the ASTM E873-82 (2006) and the higher heating value (HHV) was performed by the calorimeter bomb, using a Parr calorimetric pump and $10 \mathrm{~cm}$ of nickel-chromium fuse wire with a calorie-value of $2.3 \mathrm{cal} / \mathrm{cm}$, following the ASTM E711-87 (1996). The cellulose and hemicellulose content were determined by the difference between acid detergent (ADF) and neutral detergent (NDF), according to the methodology of Van Soest and Wine (1967). The lignin content was determined directly by the Klason method (Van Soest and Wine 1967). The protein content has been determined through the AOAC 990.03 (1989) International method, using an elementary nitrogen/protein analyzer, Flash Model 2000 from Thermo Scientific. The quantification of fat content was performed according to the Goldfish method, using hexane 
Fig. 1 Cotton stalk and shell, ground biomass, and briquette produced

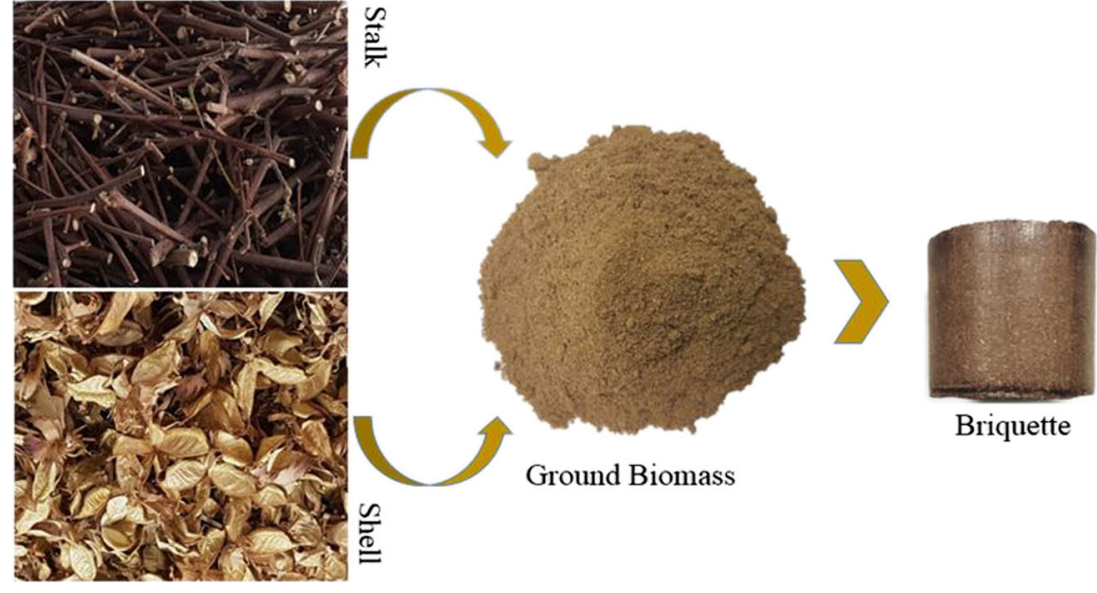

(solvent) to extract the apolar fraction of the biomass. The removal of the solvent was carried out by evaporation, with subsequent gravimetric evaluation of the apolar compounds extracted mass. The thermogravimetric analyses were carried out in $\mathrm{N}_{2}$ and air using $10 \mathrm{mg}$ of biomass, in 70- $\mu$ l alumina crucibles, heated at a rate of $10^{\circ} \mathrm{C} / \mathrm{min}$ from room temperature up to $900{ }^{\circ} \mathrm{C}$, in a thermogravimetric balance Q 500 from TA Instruments.

\section{Briquettes production}

Preliminary tests, with the biomass moisture varying between $0,8,10$, and $12 \%$ confirmed that $8 \%$ is the most suitable moisture content for producing briquettes with no fissures. The briquettes were produced in a hydraulic briquette machine of $\mathrm{O} \& \mathrm{C}$ from Brazil-Automation Hydraulics, using a cylinder mold of $45 \mathrm{~mm}$ diameter and $280 \mathrm{~mm}$ length, subjected to a pressure of 150 bar at $120^{\circ} \mathrm{C}$ during $5 \mathrm{~min}$. For each sample, a total of six briquettes containing $30 \mathrm{~g}$ each were produced. Figure 1 shows the cotton stalk and shell biomass as received, ground biomass, particle size $<5 \mathrm{~mm}$, and the briquette produced.

Table 1 Samples description

\begin{tabular}{llrr}
\hline \multirow{2}{*}{ Samples } & Cultivars & \multicolumn{2}{c}{ Composition (\%) } \\
\cline { 3 - 4 } & & Stalk & Shell \\
\hline B_ST & BRS Branco 286 & 100 & 0 \\
B_SH & BRS Branco 286 & 0 & 100 \\
B_1:1 & BRS Branco 286 & 50 & 50 \\
T_ST & BRS Topazio & 100 & 0 \\
T_SH & BRS Topazio & 0 & 100 \\
T_1:1 & BRS Topazio & 50 & 50 \\
J_ST & BRS Jade & 100 & 0 \\
J_SH & BRS Jade & 0 & 100 \\
J_1:1 & BRS Jade & 50 & 50 \\
\hline
\end{tabular}

The briquette density was determined experimentally, measuring its mass and divided by its volume calculated based on the length and diameter. The mechanical strength of each briquette was determined according to the standard NBR 7215ABNT (1996) and NBR 5739-ABNT (1994), using a standard test machine AG-I $100 \mathrm{KN}$ from SHIMADZU. The compression load was applied lengthwise over each briquette in order to have the maximum strength supported by it in the breaking point. Three briquettes of each sample were tested, using a test speed of $0.3 \mathrm{~mm} / \mathrm{min}$.

\section{Results and discussion}

The biomasses moisture content was controlled to $8 \%$. Moisture is a factor of great importance for the briquette manufacture, since it acts as a bonding agent between the particles, exerting Van der Waals forces between them (Moreno et al. 2016). When the moisture content is high, the briquettes have less durability, once that they are more susceptible to abrasion. Residues with high moisture content can have a weak ignition and reduce the combustion quality (Moreno et al. 2016; Hellwig 1985). The compositional analysis results of the studied biomasses are presented in Table 2.

According to Table 2, the stalk samples presented similar results of volatile, ash and fixed carbon content. The same was observed for the shell cotton samples. However, it was noticed that the stalk had a lower ash content, higher volatile, and fixed carbon content. High levels of volatile and fixed carbon promote the HHV, since they are chemical energy stored in the biomass (Mckendry 2002).

The stalk and shell cotton samples presented typical lignocellulosic composition (Table 2), varying between 34 and $38 \%$ of cellulose, 23 and $30 \%$ of hemicellulose, and 12 and $16 \%$ of lignin. Results were similar to other lignocellulosic biomasses, such as oat and wheat straw (Adapa et al. 2009). It is possible to infer that hemicellulose and lignin values were higher in the stalk samples. Regarding the cellulose content, it 
Table 2 Chemical composition of pure biomass samples

\begin{tabular}{lrrrrrr}
\hline \multirow{2}{*}{ Characterization } & \multicolumn{7}{l}{ Biomass samples } \\
\cline { 2 - 7 } & \multicolumn{1}{l}{ B_ST } & \multicolumn{1}{c}{ T_ST } & \multicolumn{1}{c}{ J_ST } & \multicolumn{1}{l}{ B_SH } & \multicolumn{1}{l}{ T_SH } & \multicolumn{1}{c}{ J_SH } \\
\hline Ash (\%) & $4.0 \pm 0.05$ & $5.7 \pm 0.04$ & $5.0 \pm 0.08$ & $12.0 \pm 0.07$ & $10.0 \pm 0.08$ & $11.4 \pm 0.07$ \\
Volatile (\%) & $74.8 \pm 0.03$ & $74.1 \pm 0.02$ & $75.5 \pm 0.20$ & $70.0 \pm 0.50$ & $70.8 \pm 0.03$ & $71.0 \pm 0.08$ \\
Fixed carbon (\%) & $13.2 \pm 0.07$ & $12.2 \pm 0.03$ & $11.5 \pm 0.50$ & $10.0 \pm 0.04$ & $11.2 \pm 0.06$ & $9.6 \pm 0.30$ \\
Cellulose (\%) & $34.2 \pm 0.04$ & $33.8 \pm 0.09$ & $34.5 \pm 0.04$ & $36.5 \pm 0.06$ & $37.2 \pm 0.09$ & $38.0 \pm 0.50$ \\
Hemicellulose (\%) & $26.7 \pm 0.05$ & $25.1 \pm 0.06$ & $29.8 \pm 0.09$ & $24.3 \pm 0.03$ & $23.1 \pm 0.03$ & $23.0 \pm 0.04$ \\
Lignin (\%) & $16.5 \pm 0.06$ & $16.3 \pm 0.08$ & $14.5 \pm 0.06$ & $14.2 \pm 0.06$ & $13.0 \pm 0.20$ & $12.5 \pm 0.09$ \\
Protein (\%) & $5.2 \pm 0.07$ & $3.0 \pm 0.04$ & $5.5 \pm 0.06$ & $5.0 \pm 0.08$ & $2.5 \pm 0.04$ & $2.2 \pm 0.09$ \\
Fats (\%) & $0.75 \pm 0.02$ & $1.33 \pm 0.05$ & $0.54 \pm 0.03$ & $0.40 \pm 0,1$ & $0.38 \pm 0.4$ & $0.37 \pm 0.02$ \\
\hline
\end{tabular}

was observed that it is slightly higher in the shell samples; however, there were no significant difference between parts.

The protein and fat content determination is important due to its influence as natural binder in the briquetting process, once that in the presence of heat and mechanical pressure, it can create links between the biomass particles, increasing the briquette compressive strength (Moreno et al. 2016). According to results from Table 2, the protein contents of the shell and stalk were between 2.2 and 5.5\%, and smallest protein content was observed in the stalk and shell of Topazio samples. The fat content (Table 2) of the biomasses varied from 0.37 to $1.33 \%$, being the most pronounced presence associated to the cotton stalk.

Thermogravimetric analysis (TGA) results of the samples are presented in Fig. 2, with three significant mass loss events. For the pyrolysis curves, the first event between 35 and $150{ }^{\circ} \mathrm{C}$ resulted in a mass loss between 4.5 and $12 \%$ and was associated to moisture release.

The second event is a characteristic of hemicellulose and cellulose decomposition, being responsible for most of the volatile matter content. The samples B_ST, T_ST, and T_SH presented the greatest mass loss, $\Delta m=59.5 \%, \Delta m=54.5 \%$, and $\Delta m=54 \%$, respectively, being the smallest mass loss in this event associated to the sample B_SH, $\Delta m=48.1 \%$. The last event occurred in a wide range of temperature, between 100 and $900{ }^{\circ} \mathrm{C}$, indicating the lignin degradation; however, it becomes more evident in certain temperature ranges, especially close to $400{ }^{\circ} \mathrm{C}$. Essentially, it is possible to observe that the thermal behaviors of colored species are similar to the white cotton. The results were similar to others lignocellulosic biomasses, such as banana leaves and stem (Maia et al. 2017) and pineapple crown leaves (Braga et al. 2015).

The values associated to the thermal decomposition of cellulose, hemicellulose, and lignin (second and third event), as shown in Fig. 2, are in accordance with the results of the constituents present in Table 2 . The contents of volatile, ash, and fixed carbon presented in Table 2 also corroborate with these results. According to Yang et al. (2007), the different thermal behaviors observed in each sample can be attributed to the structure and chemical nature of cellulose, hemicellulose, and lignin. Also, this author stated that the thermal decomposition of hemicellulose and cellulose occurs from 220 to $315^{\circ} \mathrm{C}$ and 315 to $400{ }^{\circ} \mathrm{C}$, respectively.

The combustion curves (Fig. 2) show three distinct mass loss events. The first event referent to moisture loss is similar to pyrolysis curves. The second, between 160 and $350{ }^{\circ} \mathrm{C}$, is associated to lignocellulosic structure decomposition. The third event, related to the char combustion, occurs between 405 and $485{ }^{\circ} \mathrm{C}$ with a mass loss ranging from 12.0 to $14.8 \%$ for the stalk samples and between 360 and $480{ }^{\circ} \mathrm{C}$ along with a mass loss between 27.0 and $29.6 \%$ for the shell samples. The higher mass loss for the shell can be explained by its ash content that ranges from 10 to $12 \%$ in comparison to the ash content of the stalk samples that ranges its content from 4.0 to $5.7 \%$.

The results of bulk density and HHV of the biomass powder, and briquette density are presented in Table 3. It is possible to observe that Jade and Topazio samples have higher heating value when compared with the white cotton. The HHV of the biomass indicates the chemical energy present in it, which is converted into thermal energy. This is the most important property of a fuel, since it determines its energy value (Erol et al. 2010).

According to Table 3, the briquette density has increased in relation to the bulk density for the powdered biomass. According to Moreno et al. (2016), densification reduces the costs of transport, handling, and storage. It is also observed that briquette densities were influenced by inorganic mineral content of biomasses, presenting the highest values to the ones with high ash content, and consequently, these showed the lowest HHV values. This tendency is also confirmed in samples formulated by the mixtures of stalk and shell. The ash content has no flammable properties and may reduce the energetic potential of the biomass for power generation (Avelar et al. 2016). 

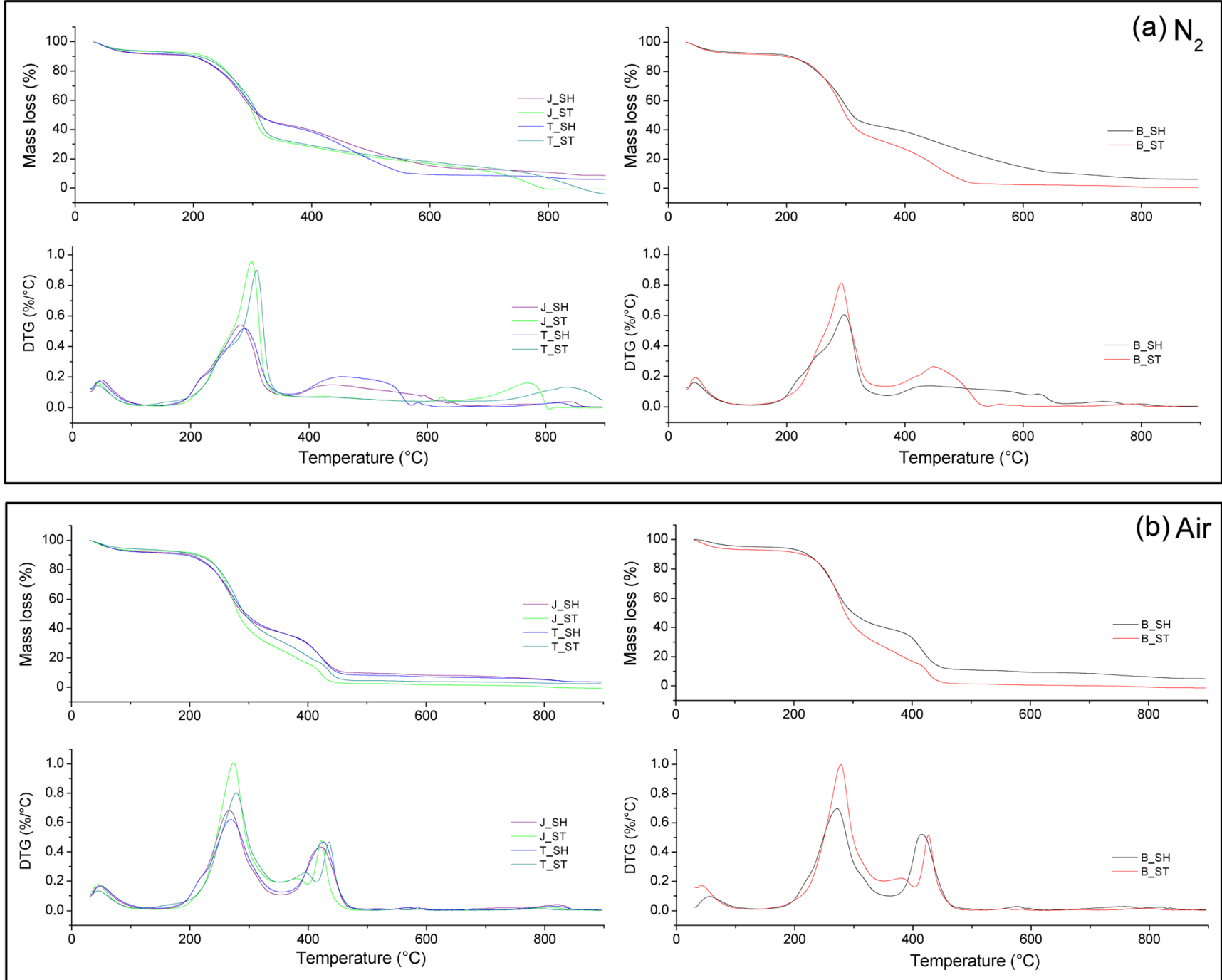

Fig. 2 Pyrolysis and combustion thermogravimetric curves (TG/DTG) of white and colored cotton samples

The results of the briquette density are in accordance with the technical specifications required by the European standard for solid biofuels in briquette form (CEN/TS 14961 2005). The briquette density is a very important parameter to determine variables related to the transport of a certain amount of energy (Gomes et al. 1997). Also, the compressive strength to quality control of this product should be considered. The compressive strength results from Fig. 3 do not show a
Table 3 Bulk density, density, and calorific strength of pure samples and mixtures

\begin{tabular}{llll}
\hline Biomass & Bulk density $\left(\mathrm{g} / \mathrm{cm}^{3}\right)$ & Briquette density $\left(\mathrm{g} / \mathrm{cm}^{3}\right)$ & HHV $(\mathrm{MJ} / \mathrm{kg})$ \\
\hline B_ST & $0.32 \pm 0.03$ & $1.12 \pm 0.4$ & $16.7 \pm 0.03$ \\
T_ST & $0.38 \pm 0.06$ & $1.20 \pm 0.7$ & $19.0 \pm 0.07$ \\
J_ST & $0.31 \pm 0.07$ & $1.12 \pm 0.3$ & $17.2 \pm 0.06$ \\
B_SH & $0.38 \pm 0.06$ & $1.14 \pm 0.3$ & $16.5 \pm 0.05$ \\
T_SH & $0.39 \pm 0.05$ & $1.28 \pm 0.6$ & $17.0 \pm 0.05$ \\
J_SH & $0.40 \pm 0.06$ & $1.27 \pm 0.6$ & $17.0 \pm 0.04$ \\
B_1:1 & $0.35 \pm 0.05$ & $1.22 \pm 0.2$ & $16.6 \pm 0.05$ \\
T_1:1 & $0.38 \pm 0.04$ & $1.27 \pm 0.2$ & $18.0 \pm 0.05$ \\
J_1:1 & $0.34 \pm 0.04$ & $1.22 \pm 0.4$ & $17.1 \pm 0.07$ \\
\hline
\end{tabular}




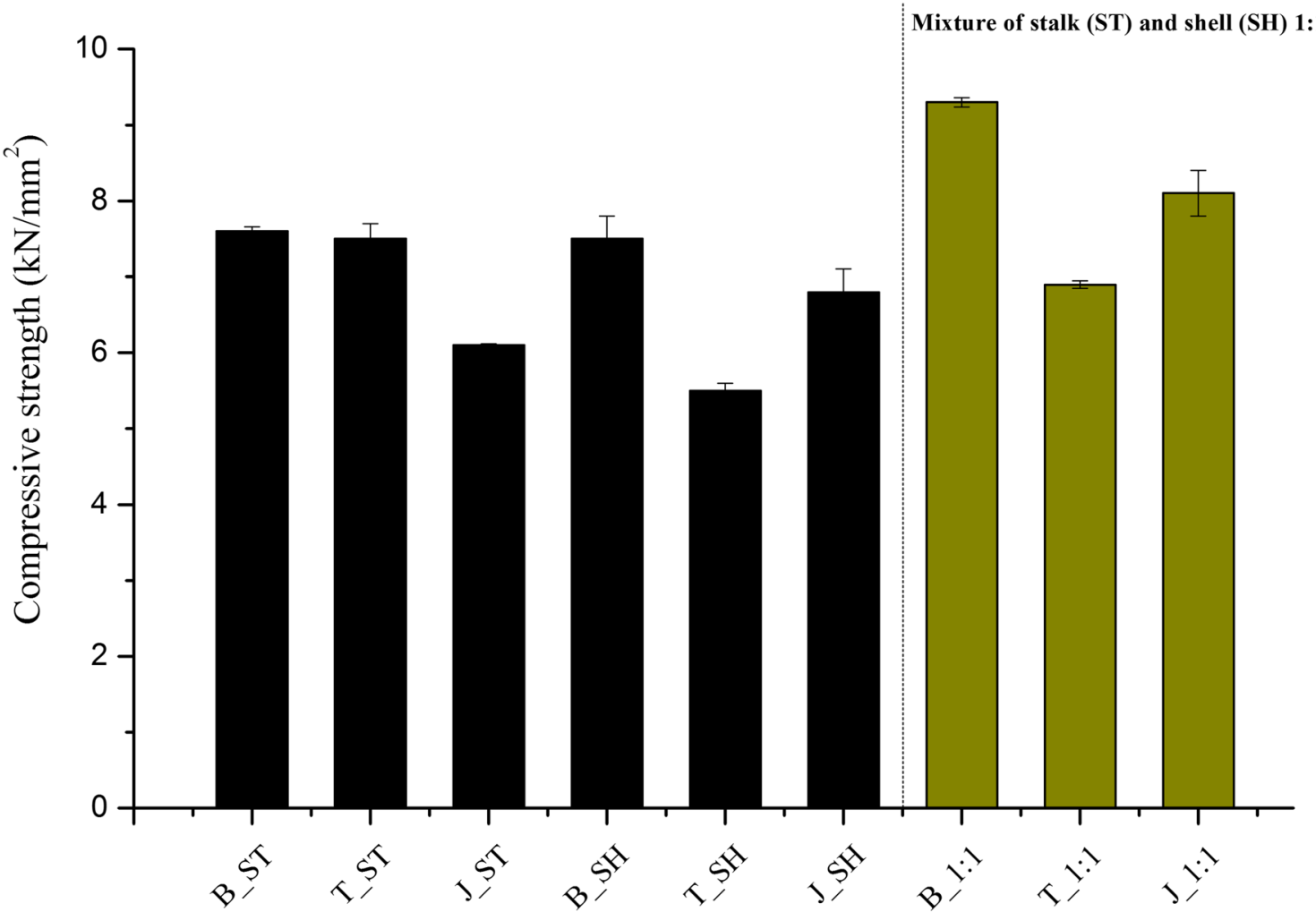

Fig. 3 Compressive strength of the briquettes produced

significant difference between parts of the Jade and white cotton species. However, a considerable increase of 20 and $23 \%$ in the compressive strength from the mixtures of those were observed, respectively.

The most suitable briquette for commercial purposes must have the ideal combination between mechanical resistance and HHV (Oliveira et al. 2017). The mechanical resistance is related to the adhesion forces between the biomass particles (Pietsch 2002). In this study, it was observed that briquettes produced with a mixture ratio of 1:1 (stalk and shell) have presented the highest protein content (B_1:1> J_1:1> $\mathrm{T}_{-} 1: 1$ ), showing the highest compressive strength values. Stability to mechanical shocks is an important viability factor for the briquette transport and commercialization (Oliveira et al. 2017).

\section{Conclusion}

The energetic characterization carried out with the Jade, Topazio, and white cotton crop waste indicated that they had a significant energy potential to be used as an alternative energy source, once that they presented considerable values of HHV, fixed carbon, and volatile matter content. The values related to density and mechanical resistances of the briquettes were greater for the biomasses mixture. These results confirm that compressive strength increasing is attributed to compositional characteristics of each part used in the briquette production, and a positive correlation was found between the protein content and mechanical strength. The use of cotton crop waste mix for briquette production besides improving the characteristics of the product can promote economic advantages, reducing the separation cost.

Acknowledgements The authors gratefully acknowledge the EMBRAPA Algodão for the sample availability, Central Analítica/ NUPPRAR/UFRN and Laboratório de Nutrição Animal from the Federal University of Rio Grande do Norte (EAJ/UFRN) for the elemental and ADF/NDF analysis, and LabTam/NUPPRAR/UFRN for the facilities.

Funding information This study was financially supported by the CNPq (Conselho Nacional de Desenvolvimento Científico e Tecnológico).

\section{References}

ABNT - Associação Brasileira de Normas Técnica (1994) NBR 5739 Concreto - Ensaio de compressão de corpos-de-prova cilíndricos. Rio de Janeiro, p 4

ABNT - Associação Brasileira de Normas Técnicas (1996) NBR 7215 Cimento Portland - Determinação da resistência à compressão. Rio de Janeiro, p 8

Adapa P, Tabil L, Schoenau G (2009) Compaction characteristics of barley, canola, oat and wheat straw. Biosyst Eng 104:335-344. https:// doi.org/10.1016/j.biosystemseng.2009.06.022 
Ali N, Saleem M, Shahzad K, Chughtai A (2015) Bio-oil production from fast pyrolysis of cotton stalk in fluidized bed reactor. Arab J Sci Eng 40:3019-3027. https://doi.org/10.1007/s13369-0151801-z

ASTM 1755-01 (2015) Standard test method for ash in biomass. American Society for Testing and Materials (ASTM), Philadelphia

ASTM E 711-87 (1996) Standard test method for gross calorific value of refuse-derived fuel by the bomb calorimeter. American Society for Testing and Materials (ASTM), Philadelphia

ASTM E 872-82 (2013) Standard test method for volatile matter in the analysis of particulate wood fuels. American Society for Testing and Materials (ASTM), Philadelphia

ASTM E 873-82 (2006) Standard test method for bulk density of densified particulate biomass fuels. American society for testing and materials (ASTM), Philadelphia

Avelar NV, Rezende AAP, Carneiro ACO, Silva CM (2016) Evaluation of briquettes made from textile industry solid waste. Renew Energy 91:417-424. https://doi.org/10.1016/j.renene.2016.01.075

Bianchini A (2004) Eliminar é preciso. Cultivar Máquinas, 27. In: https:// www.grupocultivar.com.br/artigos/eliminar-e-preciso. Accessed 25 June 2018

Braga RM, Queiroga TS, Calixto GQ, Almeida HN, Melo DMA, Melo MAF, Freitas JCO, Curbelo FDS (2015) The energetic characterization of pineapple crown leaves. Environ Sci Pollut Res 22:1898718993. https://doi.org/10.1007/s11356-015-5082-6

CEN/TS 14961 (2005) Solid biofuels. Fuel specifications and classes. British Standards Institution. Comite Europeen de Normalisation (CEN), London

Coates W (2000) Using cotton plant residue to produce briquetes. Biomass Bioenergy 18:201-208. https://doi.org/10.1016/S09619534(99)00087-2

Companhia Nacional de Abastecimento - CONAB (2017) Perspectiva para a agropecuária: Produtos de Verão - Safra 2017/2018, Volume 5, Brasília

Erol MH, Haykiri-Acma, Küçükbayrak S (2010) Calorific value estimation of biomass from their proximate analyses data. Renew Energy 35:170-173. https://doi.org/10.1016/j.renene.2009.05.008

Gomes RS, Wilson PN, Coates WE, Fox RW, (1997) Cotton (Gossypium) plant residue for industrial fuel. Ind Crop Prod 7(1): $1-8$

Hellwig G (1985) Basic of the combustion of wood and straw. In: Palz W, Coombs J, Hall DO, (eds) Energy from biomass, 3rd edn. Elsevier Applied Science, London, p 793-798. E.C. Conference

International Methods 990.03 (1989) Protein (erude) in animal feed. Combustion methods. Association of Official and Analytical Chemists. J AOAC Int 72:770
Jenkins BM, Sumner HR (1986) Harvesting and handling agricultural residues for energy. Trans ASAE 29(3):824-836. https://doi.org/ $10.13031 / 2013.30236$

Ji-Lu Z, Wei-Ming Y, Na-Na W (2008) Bio-oil production from cotton stalk. Energy Convers Manag 49:1724-1730. https://doi.org/10. 1016/j.enconman.2007.11.005

Madhu P, Kanagasabapathy H, Manickam IN (2016) Cotton shell utilization as a source of biomass energy for bio-oil by flash pyrolysis on electrically heated fluidized bed reactor. J Mater Cycles Waste Manag 18:146-155. https://doi.org/10.1007/s10163-014-0318-y

Maia BGO, Oliveira APN, Oliveira TMN, Marangoni C, Souza O, Sellin N (2017) Characterization and production of banana crop and rice processing waste briquettes. Environ Prog Sustain Energy. https:// doi.org/10.1002/ep.12798

Mckendry P (2002) Energy production from biomass (part 1): overview of biomass. Bioresour Technol 83:37-46. https://doi.org/10.1016/ S0960-8524(01)00118-3

Moreno AI, Front R, Conesa JA (2016) Physical and chemical evaluation of furniture waste briquettes. Waste Manag 49:245-252. https://doi. org/10.1016/j.wasman.2016.01.048

Nikhilesh S, Trivedi SA, Mandavgane, Ashish C (2018) Characterization and valorization of biomass char: a comparison with biomass ash. Environ Sci Pollut Res 25:3458-3467. https://doi.org/10.1007/ s11356-017-0689-4

Oliveira RS, Palácio SM, da Silva EA, Mariani FQ, Reinehr TO (2017) Briquettes production for use as power source for combustion using charcoal thin waste and sanitary sewage sludge. Environ Sci Pollut Res 24:10778-10785. https://doi.org/10.1007/s11356-017-8695-0

Pietsch W (2002) Agglomeration processes - phenomena, technologies, equipment. Wiley, 624p, Weinheim. https://doi.org/10.1002/ 9783527619801

Shone CM, Jothi TJS (2016) Preparation of gasification feedstock from leafy biomass. Environ Sci Pollut Res 23:9364-9372. https://doi. org/10.1007/s11356-015-5167-2

Van Soest PJ, Wine RH (1967) Use of detergents in the analysis of fibrous feeds. IV determination of plant cell-wall constituents. J Assoc Off Anal Chem 50:50-55

Yang H, Yan R, Chen H, HoLee D, Zheng C (2007) Characteristics of hemicellulose, cellulose and lignin pyrolysis. Fuel 86:1781-1788. https://doi.org/10.1016/j.fuel.2006.12.013

Zhu S-W, Gao P, Sun J-S, Wang H-H, Luo X-M, Jiao M-Y, Wang Z-Y, Xia G-X (2006) Genetic transformation of green-colored cotton. In Vitro Cell Dev Biol Plant 42:439-444

Publisher's note Springer Nature remains neutral with regard to jurisdictional claims in published maps and institutional affiliations. 